\title{
Pregnancy Indicator
}

National Cancer Institute

\section{Source}

National Cancer Institute. Pregnancy Indicator. NCI Thesaurus. Code C139264.

An indication as to whether the individual is pregnant. 